\title{
Ranking of invasive spread through urban green areas in the world's 100 most populous cities
}

\author{
Cang Hui $\mathbb{D} \cdot$ David M. Richardson $(\mathbb{D} \cdot$ - Vernon Visser $(\mathbb{D}$
}

Received: 29 May 2017 / Accepted: 14 June 2017/Published online: 16 October 2017

(C) Springer International Publishing AG 2017

\begin{abstract}
Urban landscapes are highly fragmented (leading to the extinction of native species) as well as transformed and disturbed (creating novel environments). Such conditions provide non-native species with opportunities to establish and spread through "urban green areas" (UGAs). UGAs can serve as stepping stones for many alien species to recruit and may become sources of propagules to launch invasions in adjoining natural ecosystems. There is great diversity in the spatial structures of UGAs worldwide; these
\end{abstract}

Guest Editors: Mirijam Gaertner, John R.U. Wilson, Marc W. Cadotte, J. Scott MacIvor, Rafael D. Zenni and David M.

Richardson/Urban Invasions.

C. Hui $(\square)$

Centre for Invasion Biology, Department of Mathematical Sciences, Stellenbosch University, Matieland 7602, South Africa

e-mail: chui@sun.ac.za

C. Hui

Theoretical Ecology Group, African Institute for

Mathematical Sciences, Cape Town 7945, South Africa

D. M. Richardson

Centre for Invasion Biology, Department of Botany and Zoology, Stellenbosch University, Matieland 7602, South Africa

\section{Visser}

Centre for Statistical Ecology, the Environment and Conservation, Department of Statistical Sciences,

University of Cape Town, Cape Town 7700, South Africa are determined by the city's level of development, human density, urban planning policy, and history. We explore the invasion risks of, and the potential of invasive spread in, UGAs in the world's 100 most populous cities (in 40 countries). Based on maps of enhanced vegetation index at $250 \mathrm{~m}$ resolution over the extent of 25 by $25 \mathrm{~km}$ for each city centre, we simulate the invasion and spread of a reference species (a virtual ruderal invasive species) from the city centre into surrounding urban or rural areas. Doing so allowed us to provide an objective baseline for comparing urban susceptibility to such invasions across diverse cultures, histories and societies. We derive the global ranking of invasive spread potential for each city based on the rate of spread of the reference species, and the ranking of 40 countries, based on the average rate of spread in their cities. We explore correlates of spread rates after 100 time steps (years) by examining the roles of climate (mean annual temperature and rainfall), human demography (city population size and growth rate), and socioeconomic indicators [human footprint, human development index and gross domestic product (GDP) per capita]. Small city population size and high GDP per capita are the only significant predictors of high potential for invasive spread. Among the G20 countries, Canada, South Korea, South Africa, France, USA and Brazil all feature in the top-10 countries, and Atlanta, Washington, D.C. and Dallas in the USA, Chittagong in Bangladesh, Toronto in Canada and 
Brasilia in Brazil are listed among the top 10 cities overall. Our results can serve as a global baseline assessment of invasive spread risks through UGAs, and call for improved protocols for monitoring, planning and management of UGAs.

Keywords Biological invasions · Invasion dynamics - Global ranking - Invasion risk - Spread . Urban greenspaces

\section{Introduction}

It is predicted that by $205064 \%$ of people in the developing world and $86 \%$ in the developed world will live in urban environments (UNFPA 2007). Urban ecosystems, ranging from megacities to suburban areas, are the frontline for biodiversity conservation. This is because urbanization is especially fast in developing nations where much of the world's biodiversity is located, and this is where development and conservation often lead to conflicts. As hubs for energy and material consumption, urban areas are often associated with elevated temperatures, nutrient and pollution deposition, dispersal pathways, propagule movement and disturbance; such changes create altered selection forces for novel assemblages of 'urban winners' (McKinney 2008). Although the ways in which urban systems facilitate the invasion and spread of invasive non-native species have been fairly well documented (e.g. Hui and Richardson 2017), a global synthesis of the drivers of urban invasive spread has yet to be undertaken. It is important to note that here we are not exploring the issue of invasiveness (what makes species A more invasive than species B in a city), but rather focus on the comparison of invasibility of global cities (what makes city A more susceptible to invasion than city B).

If we examine the invasion dynamics of similar species in different environments, a complicated picture emerges. Some species will show a conservative range, whereas others are expanding, retracting, or shifting their current ranges. As the geographic ranges of many species, native or introduced, are expected to change in response to ongoing global environmental changes (Thomas et al. 2004), invasive species will not only respond to these changes but also expand their ranges into suitable habitat as a process of niche filling. As such, the range dynamics of native species reflect the tracking of their suitable habitat. In contrast, the range dynamics of invasive species depict both the spread into their potential suitable habitat and track the changes in suitable habitat. The range dynamics of natives and invasives, thus, differ fundamentally (Hui and Richardson 2017). Invasive species often experience a large spatial variation in their spreading rates (spatial discordance). For instance, common starlings spread at half the speed in the southern hemisphere compared to North America (Hui et al. 2012). It is important to determine whether differences in the environments in these localities are responsible for differences in the dispersal strategy and the population growth rate, and thus responsible for the spatial variation of spreading patterns. Other examples of spatial discordance include the speckled wood butterfly, Pararge aegeria, in Britain (Hill et al. 2001), with spread rates of $0.51 \mathrm{~km} / \mathrm{yr}$ in England and $0.93 \mathrm{~km} / \mathrm{yr}$ in Scotland attributable to the greater cover of woodland in Scotland. Lyons and Scheibling (2009) examined the spread dynamics of five prominent introduced algae (Codium fragile, C. taxifolia, Grateloupia turuturu, S. muticum, and Undaria pinnatifida) and detected a large variation in the rate of expansion for individual species between regions, suggesting a complex interplay between algal traits, attributes of invaded regions and anthropogenic factors.

Such spatial variation in spreading rates could be explained by local geographically specific abiotic and biotic conditions under which the newcomers must survive and reproduce (Carroll and Dingle 1996). Evolutionary response to these environmental challenges often leads to new life-history strategies in the invading population (Yoshida et al. 2007). Therefore, introduced populations of an invasive species may ultimately diverge in important life-history traits in response to selection pressures in the novel environment, as shown for the Mediterranean fruit fly, Ceratitis capitata, by comparing six populations originating from different regions (Diamantidis et al. 2009). Moreover, the discordance in the invasion dynamics can be caused by demographic or genetic stochasticity; such endogenously generated variance in spread rates can be remarkably high, as demonstrated in replicated spreading trials of the flour beetle, Tribolium castaneum, in laboratory microcosms 
(Melbourne and Hastings 2009), which seriously compromises our ability to predict spread dynamics.

Important features of urban environments are that, on the one hand, they thwart the establishment and persistence of any species but, on the other, they favour temporal turnover (within-patch extinction rates) and the movement of invasive propagules. Persistence of invasive species at local scales can be significantly lower in an urban environment (Pergl et al. 2012). Many non-native plant species have limited opportunities to establish and spread in the fragmented habitats that exist in urban areas which results in limited abundance and invasiveness (Donaldson et al. 2014). Moreover, vehicles accelerate propagule movement and contribute significantly to long-distance dispersal events, especially along roadsides; this is especially the case for highly invasive species (Von der Lippe and Kowarik 2007). Spread rates from nearest-neighbour diffusion can reach $1-5 \mathrm{~km}$ per year, and maximum spread rates due to long-distance dispersal events are an order of magnitude greater (Aikio et al. 2010). Therefore, to simulate or monitor the spread of invasive non-native plants, it is essential to include both local and long-distance dispersal. Insights such as these suggest that even without detailed knowledge of the biology and dispersal pathways of individual species, patch-level events of colonization (including both dispersal and subsequent establishment) and extinction could be sufficient to capture the essence of landscape-scale spread dynamics of invasive non-native plants in urban areas.

A constant influx of propagules or a persistent source population could significantly reduce the uncertainty and stochasticity during spread in urban environments. Suburban gardens serve as an important source of non-native propagules (Alston and Richardson 2006; McLean et al. 2017). Often, a single tree (e.g. in the case of an invasion in New Hampshire by Kalopanax septemlobus) can sustain a vigorous alien population (Lee et al. 2015). Housing developments, especially in low-density residential areas, have facilitated the invasion of horticultural plants by disturbing surface soils and enhancing dispersal along road-verges (Gravier-Pizarro et al. 2010). Urban riparian habitats may also act as hubs and sources for further spread of non-native species (Pyšek et al. 1998; Meek et al. 2010; Dyderski et al. 2015). Urban environments also have fragmented habitats, promoting invasions along habitat boundaries (Cilliers et al. 2008; Song et al. 2003). In urban coastal habitats in the Mediterranean Basin, the abundance of nonnative plant species was found to be most strongly influenced by patch shape and land-cover changes within patches and the composition of the surrounding landscape (50 $\mathrm{m}$ buffer) (Basnou et al. 2015). The boundaries of urban green areas (UGAs; defined as street trees, sidewalk gardens, parks and backyard gardens), therefore, could channel the dissemination of non-native propagules. The dynamics and structure of urban landscapes can indirectly facilitate invasions by altering disturbance regimes and breaking down dispersal and establishment barriers through transforming urban land-use (e.g. housing development).

Given such diverse features of urban environments, ranking cities across the globe according to their potential for invasive species spread is challenging. A global ranking of the potential and rate of invasive spread provides us an objective baseline for comparing urban susceptibility to invasions across diverse cultures, histories and societies, paving the way for further generalisation on the drivers behind urban invasions. Here, we propose the use of simulation, specifically of a universal reference species in dynamic urban landscapes from remote sensing, as a model for assessing and comparing invasion risks in cities. The reference species experiences colonization from establishment after local and long-distance dispersal, initiated from a single permanent source, and extinction due to the harsh urban environment and frequent disturbance. More specifically, we could consider this virtual reference invader an urban winner, including many ruderal herbaceous and shrub species (e.g. the Japanese knotweed Fallopia japonica, the pompom weed Campuloclinium macrocephalum, or the annual weed Crepis sancta). Colonization and extinction are assumed to be context-dependent over dynamic landscapes. By modelling the spread of this reference species over the world's 100 most populous cities, we are able to perform a reasonable comparison of the invasion risks, or more precisely the potential of invasive spread of the reference species, facing these cities, and further explain the variation of the potential invasive spread by demographic, climate and socioeconomic factors. Again, we need to emphasize that the intention of using a simulated reference species here is not to imitate any existing invasive species; rather, through 
using this reference species that can spread in most global cities, we could use the relative spreading rate, not the absolute spreading rate which carries little meaning, to rank the potential invasive spreading rate across global cities.

\section{Methods}

Data

We selected the world's 100 most populous cities (UN, DESA, PD 2014) to represent a spectrum of development levels, climates and geographical regions (40 countries from all continents except Antarctica; Fig. 1). Countries with the highest numbers of cities in the list include China (24), USA (11), India (9), Brazil (5) and Japan (4), with the rest having mostly only one (24 countries) or two cities. For each city, we obtained remotely-sensed MODIS MOD13Q1 16-day $250 \mathrm{~m}$ resolution surface reflectance data (Didan 2015) for the middle month of all four seasons (March, June, September and December). For each season we calculated an average for the enhanced vegetation index (EVI) MOD13Q1 layer over the years 2013, 2014 and 2015 to avoid extremeclimate anomalies. The exact location of each grid within the city was chosen according to the coordinates provided in the World database of large urban areas, 1950-2050 (Ahlenius 2010). Due to the great heterogeneity within cities, the selection of the grid location will undoubtedly affect the subsequent analyses. However, due to the difficulties of obtaining a standardized "central" location for each city, we relied solely on the coordinates provided in Ahlenius (2010). We cropped each tile to a grid of $25 \times 25 \mathrm{~km}$ $\left(625 \mathrm{~km}^{2}\right)$, representing 10,000 cells per grid, centred on each city's coordinates, and used these in the simulations. Ground-truthing using Google Earth suggests that cells with EVI $>0.4$ contain notable green spaces.

For each grid, we obtained seven predictors to explain the variation of invasion risks realised from the simulation model. These predictors include two climatic variables [mean annual precipitation, MAP, and mean annual temperature, MAT, for the years 1960-1990 from WorldClim; Hijmans et al. (2005)], two demographic variables [city population size at 2010, POP, and city population growth rate from 2010 to 2015, PGR, from the UN World Urbanization Prospects; UN, DESA, PD (2014)] and three socioeconomic variables [human footprint index, HF; WCS and CIESIN (2005); GDP per capita at purchasing power parity, GDPpc; Berube et al. (2015); and the country-level human development index, HDI, UNDP (2015)]. HF is an index of anthropogenic impacts on the environment based on e.g. human population density (WCS and CIESIN 2005), land use and transport networks. HDI is an index representing the average of three key areas of human development: life expectancy, education and standard of living (UNDP 2015). We also collected data for other variables but decided to remove them from the analysis because of

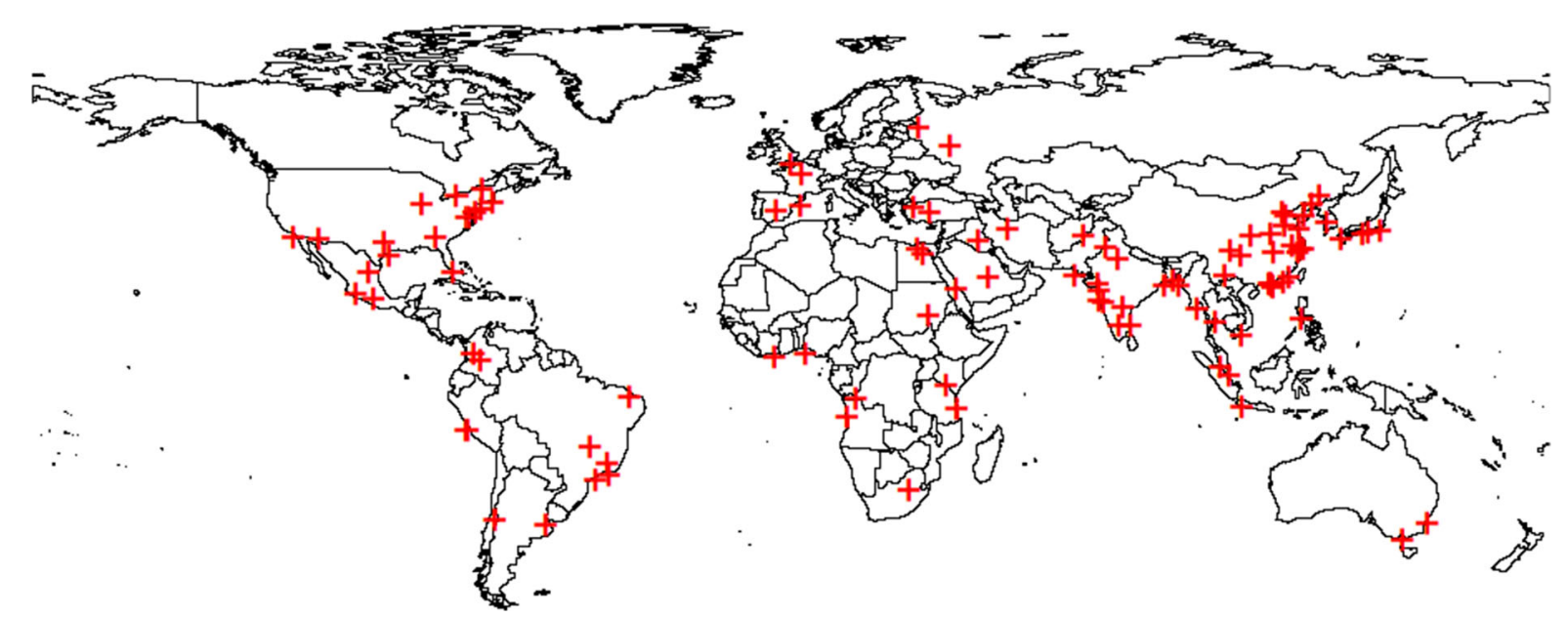

Fig. 1 Geographical locations of the world's 100 most populous cities selected for the study 
missing values for many cities and issues of collinearity with the other seven explanatory variables.

Simulation and analyses

Many approaches exist for modelling the spatiallyexplicit spread dynamics of invasive plants (Hui et al. 2011; Hui and Richardson 2017). Lattice models that implement metapopulation processes of colonization and local extinction have been widely used for simulating spread of invasive species (e.g. RouraPascual et al. 2009; Caplat et al. 2014; Donaldson et al. 2014). A simpler version of such models is the cellular automaton which has a finite number of cell statuses (in our case being established or absent). The transition probabilities of colonization of an empty cell and extinction of an established population during one time step (normally 1 year) are computed based on adjacent-cell and landscape-wide propagule pressure as well as within-cell habitat quality. Such models are normally coded as a rule-based iterative loop for specified time steps, with the status of all cells simultaneously updated based on the transition probability at each time step. The model gives a standard output of the spatial distribution of simulated species as occupied and absent cells in the landscape for each time step. The spatial structure and the rate of spread can then be easily calculated from the model output. Note that we chose to implement dispersal of propagules into a cell occurring only from two sources (adjacent cells and the entire landscape). The reason for doing so is for computational efficiency given the amount of heterogeneous EVI landscapes needed to be considered (around 12 computational hours for our simulations). Using specific dispersal kernels is computationally demanding (estimated 312 computational days) but has been shown to create reasonable spreading dynamics (e.g. Roura-Pascual et al. 2009; Donaldson et al. 2014). In addition, Brockmann et al. (2006) found that human travel can range from a few to thousands of kilometres with a power law dispersal kernel for distance above $10 \mathrm{~km}$ but a uniform distribution for travelling within a $10 \mathrm{~km}$ radius. This further justifies our model simplification on dispersaleither through natural dispersal from adjacent cells or landscape-wide human-facilitated uniform dispersal.

The simulation of a reference plant species was developed for each city grid containing $10^{4}$ cells. Before the simulation, we first identified the best and worst season for the simulated invasion based on the total EVI scores across all cells. The species was then introduced to the cell at the centre of a grid. If this cell represented a water body (with a negative EVI score), a randomly selected terrestrial cell was selected in replacement. We repeated this procedure until the cell of introduction point could be determined. We kept this introduction cell occupied throughout the simulation to mitigate stochasticity. We assumed an absorptive boundary of the grid, meaning that populations moving out of the grid boundary are considered lost in the simulation. At each time iteration, we assessed and updated the status of each cell in the grid, $\mathrm{P}_{\mathrm{i}, \mathrm{j}}=1$ (present) or 0 (absent). The occupancy at a particular time step can be estimated as the summation of $\mathrm{P}_{\mathrm{i}, \mathrm{j}}$ across all cells, denoted as $\mathrm{O}_{\mathrm{t}}$. If a cell was found already occupied by the introduced species, the resident population then faced a probability of local extinction. The probability of local extinction for a particular cell was set according to its EVI score from the worst season, $\mathrm{EXT}_{\mathrm{i}, \mathrm{j}}=\mathrm{c} \cdot\left(1-\mathrm{EVI}_{\mathrm{i}, \mathrm{j}}\right.$,worst $)$, where $\mathrm{c}$ is a coefficient. This means that the populations in cells with higher values of EVI during the worst season suffer lower probability of local extinction. That is, ameliorated conditions during the worst season can reduce the probability of extinction. If a cell was found to not contain the introduced species, the cell then faced a probability of colonization. As explained above, the probability of colonization was composed of two parts: local colonization from potential populations of any of the four adjacent cells $\left(\mathrm{LC}_{\mathrm{i}, \mathrm{j}}=\mathrm{EVI}_{\mathrm{i}, \mathrm{j} \text {,best }}\left(\mathrm{P}_{\mathrm{i}+1, \mathrm{j}}+\mathrm{P}_{\mathrm{i}-1, \mathrm{j}}+\mathrm{P}_{\mathrm{i}, \mathrm{j}+1}+\mathrm{P}_{\mathrm{i}, \mathrm{j}-1}\right) / 4\right)$ and probability of landscape-wide (global) colonization from any other populations in the grid $\left(\mathrm{GC}_{\mathrm{i}, \mathrm{j}}=\right.$ $\mathrm{EVI}_{\mathrm{i}, \mathrm{j}, \text { best }} \mathrm{O}_{\mathrm{t}} / 10^{4}$ ); note that these probabilities were assumed to be proportional to the EVI of the cell in the best season. The choice of four adjacent cells in the simulation only affect the absolute spreading rate, not the relative rate for comparison. The two parts were then weighted to produce the colonization probability, $\mathrm{COL}_{\mathrm{i}, \mathrm{j}}=\mathrm{w} \cdot \mathrm{LC}_{\mathrm{i}, \mathrm{j}}+(1-\mathrm{w}) \cdot \mathrm{GC}_{\mathrm{i}, \mathrm{j}}$, where $\mathrm{w}$ is the contribution of local dispersal to successful colonization. Essentially, colonization provides the opportunity for propagules arriving in the cell to establish when conditions are good. Consequently, the two probabilities, $\mathrm{EXT}_{\mathrm{i}, \mathrm{j}}$ and $\mathrm{COL}_{\mathrm{i}, \mathrm{j}}$ can fully describe the stochastic process of invasive spread across the grid. For cross-city comparison, we set this species as a reference with $\mathrm{c}=0.05$ (meaning that a cell with 
$\mathrm{EVI}_{\text {worst }}=0.4$ has a $3 \%$ chance to become extinct during one time step) and $\mathrm{w}=0.99$ (meaning that $99 \%$ of propagules landing in an empty cell are from local dispersal; the chance for an empty cell, with $\mathrm{EVI}_{\text {best }}=0.4$, one adjacent population and ten nonadjacent populations in the landscape, being occupied is $10.1 \%$ during one time step). The choice of the parameters ensured the survival of this references species in a wide range of environments. The model was implemented in Mathematica version 11.0 (Wolfram, Inc.).

We estimated the rate of spread as the slope from the linear regression of the square root of occupancy over 100 time steps (years), and thus with a unit of $250 \mathrm{~m} / \mathrm{yr}$. The city ranking was then derived based on the rate of spread of the reference species, while the country ranking was estimated according to the average rate of spread for those cities of the country included in the top 100 cities. The ranking and the (average) rate of spread can be considered a baseline invasion risk index. A general linear model was fitted to the data to explain the simulation-generated rate of spread by the seven explanatory variables. Multicollinearity among the seven explanatory variables was tested by the variance inflation factor (all VIFs $<5$ ) using the fmsb package in $\mathrm{R}$ (Nakazawa 2015). Independent, joint and total contributions of each explanatory variable were estimated using the hier.part package in R (Walsh and MacNally 2013).

\section{Results}

The spreading dynamics as generated from the model are reasonably realistic (Fig. 2): in Toronto, for example, the expansion started from the big green area between Harvergal College and Chatsworth Ravine, moved towards Forest Hill then Chestnut Hills in the southwest, eventually through residential areas reaching the big green areas of Toronto Island (bottom right) and High Park (bottom centre). On the eastern side, it first established in Tam O'Shanter residential area and returned to fill the gap around Parkwoods and Don Mills. Of course, this is only from one run of the model. Different expansion routes will emerge from other runs even with the same model parameters and the initial introduction point, due to the stochastic processes implemented in the model. Evidently, range expansion involved two processes, as has often been reported for invasion dynamics (Hui and Richardson 2017)-continuously expanding/growing the range largely through local dispersal, and budding population foci establishing far from the introduction point through longdistance dispersal. The reference species did not expand its range in an isotropic way, but rather followed linear features of high EVI scores. Not all budding populations eventually formed a viable source for further expansion. Note the two budding populations at time step 50 in the northeast of Toronto (arrows in Fig. 2): one clearly has not expanded its range subsequently, while the other has clearly become the source of expansion to the surrounding area.

The spread rate for the world's 100 most populous cities ranged from zero (unable to establish viable populations in London, Beijing, Cairo and Mumbai) to above 200 m/yr (in Atlanta and Washington D.C.); see Table 1. The spread of the reference species is above $100 \mathrm{~m} / \mathrm{yr}$ for the top 17 cities (Atlanta to Seoul), 100-50 m/yr for cities ranked from 18 (Johannesburg) to 34 (Singapore), $50-20 \mathrm{~m} / \mathrm{yr}$ for cities ranked from 35 (Chongqing) to 68 (Karachi), 20-10 m/yr for cities ranked from 69 (Tehran) to 84 (Jinan), $<10 \mathrm{~m} / \mathrm{yr}$ for cities ranked above 85 (Jakarta). Of the top ten ranked cities, four are from North America (Atlanta, Washington, D.C. and Dallas of the USA, and Toronto of Canada), four from South Asia (Yangon of Myanmar, Chittagong of Bangladesh, Ahmadabad and Surat of India), one from South America (Brasilia, Brazil), and one from Africa (Kinshasa, Democratic Republic of Congo). When the rate of spread was averaged for cities of a country (Table 2), the top countries included two South Asian countries (Myanmar and Bangladesh), two North American countries (USA and Canada), three African countries (DRC, Kenya, and South Africa), and one country each from East Asia (South Korea), Europe (France) and South America (Brazil). Of the countries with more than three cities, USA, Brazil and India were among those facing high risks, while China, Mexico and Japan were facing moderate to low invasion risks, with the spreading rate of Mexico and Japan around $10 \mathrm{~m} / \mathrm{yr}$.

Clearly, within cities the spreading dynamics of the reference species, as implemented in the model, are primarily determined by the spatial structure and the level of EVI scores of the urban areas. Between cities, climate, demographic and socioeconomic factors can explain a significant albeit minority of the variation observed for the spreading rate across the globe 
Fig. 2 The spread of the reference species over Toronto, Canada, measured as the square root of the number of occupied cells with respect to time steps. Insets are two snapshots at time step 50 (left) and 100 (right), with the background the EVI in the harsh season (lighter cells with higher values of EVI); occupied cells are marked as red; white arrows point at two specific budding populations from longdistance dispersal

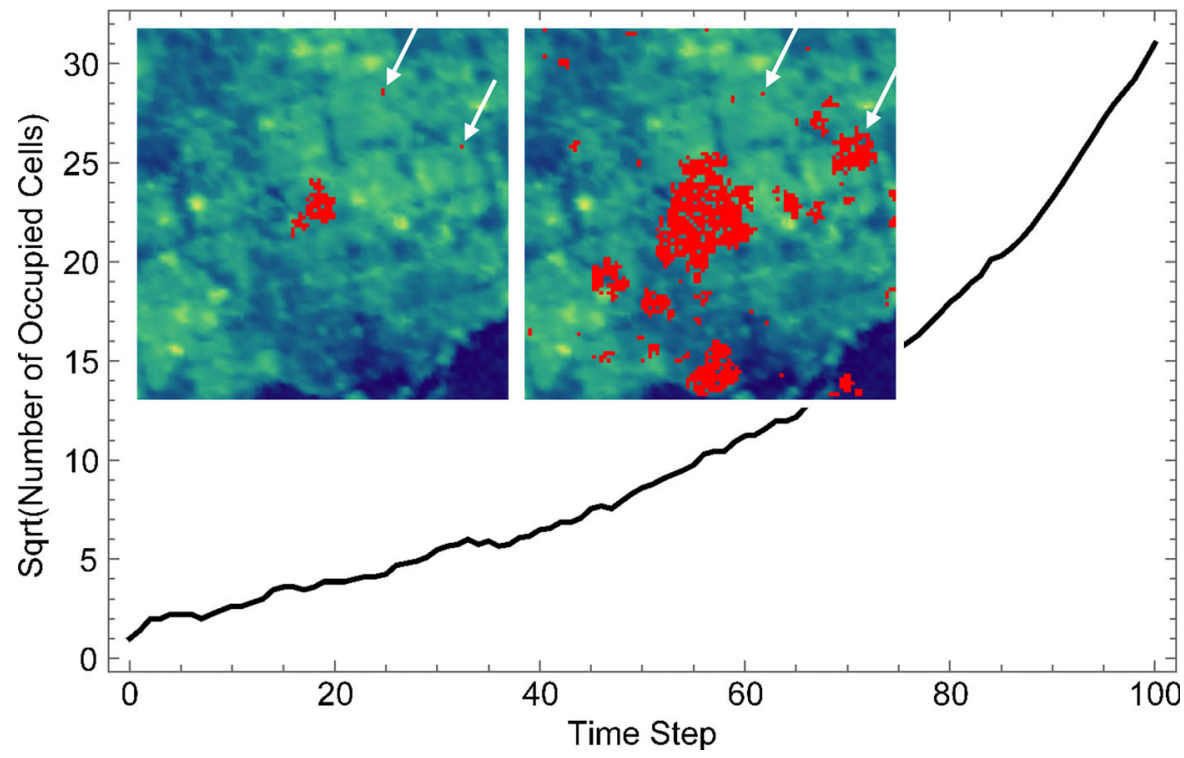

$\left(\mathrm{R}^{2}=0.265 ;\right.$ adjusted $\mathrm{R}^{2}=0.194 ; \quad \mathrm{F}_{7,73}=3.756 ;$ $\mathrm{P}=0.0016$; residual dispersion $=0.027$; Table 3). Two non-climatic factors were found to be significant (city population size, POP, and GDP per capita, GDPpc). High invasion risks are associated with smaller urban population size and higher GDP per capita. Human footprint was also found to be positively associated with invasion risks, although not significantly so $(\mathrm{P}=0.09$; Table 3$)$. Neither of the two climatic variables was found to be associated with invasion risks. Of the variance explained, GDP per capita contributed to around $40 \%$ independently, while urban population size around $36 \%$, with mean annual precipitation contributing around 10\% (Fig. 3). Human footprint and human development index contributed 6.4 and $5.3 \%$, respectively, of the explained variation (Fig. 3). Urban population growth rate and mean annual temperature contributed little $(<1 \%)$ to the explained variation of spreading rate across cities. Overall, high GDP per capita and small urban population size are significant predictors of high invasion risks, while high mean annual precipitation, large human footprint and high human development index are also weakly contributing to high invasion risks in urban areas.

\section{Discussion}

By imposing a virtual species (resembling pompom weed Campuloclinium macrocephalum, the annual weed Crepis sancta or crofton weed Ageratina adenophorum) over a $25 \times 25 \mathrm{~km}$ landscape described by its seasonal EVIs, we were able to contrast the potential of invasive spread (and thus the risks from such invasions) for 100 cities across the globe. As notable UGAs can be detected in landscapes with EVI $>0.4$ using Google Earth, spreading in a homogenous landscape with EVI $=0.4$ can be considered a baseline under our model setting, with its instantaneous rate of spread around $1.33 \mathrm{~m} / \mathrm{yr}$ according to Hui et al. (2011). Faster spreading thus relies on the presence of more or greener UGAs in the urban landscape. From this simulation, we derived a global mean rate of spread of $49.16 \mathrm{~m} / \mathrm{yr}$, a standard deviation of $47.75 \mathrm{~m} / \mathrm{yr}$, a median value of $31.96 \mathrm{~m} / \mathrm{yr}$ and a maximum rate of $233.5 \mathrm{~m} / \mathrm{yr}$ in Atlanta, USA (Table 1). These estimates are in line with those from the literature, with introduced plants estimated to spread at an average rate ranging from 2 to $370 \mathrm{~m} / \mathrm{yr}$ (Pyšek and Hulme 2005). We also like to highlight the difference between within-city local-scale spreading (normally $<1 \mathrm{~km} / \mathrm{yr}$ ) versus most reported cases of regional/geographical range expansion in the literature (normally $>10 \mathrm{~km} / \mathrm{yr}$ ). Rate of spread can drastically change due to the scale of the study and the changes in dispersal pathways and vectors, especially those facilitating long-distance dispersal (Hui and Richardson 2017). However, our intention was not to generate realistic estimates of spreading rates; rather, 
Table 1 The global ranking of invasion risks measured as the spreading rate for top 100 cities

\begin{tabular}{|c|c|c|c|c|c|c|c|c|c|c|c|}
\hline Rank & City & Speed & Rank & City & Speed & Rank & City & Speed & Rank & City & Speed \\
\hline 1 & Atlanta & 0.9341 & 26 & Hyderabad & 0.2587 & 51 & Monterrey & 0.1260 & 76 & Zhengzhou & 0.0664 \\
\hline 2 & $\begin{array}{l}\text { Washington, } \\
\text { D.C. }\end{array}$ & 0.8047 & 27 & Bangkok & 0.2547 & 52 & Xi'an & 0.1193 & 77 & Santiago & 0.0632 \\
\hline 3 & Brasilia & 0.6681 & 28 & Istanbul & 0.2511 & 53 & Shantou & 0.1164 & 78 & Chengdu & 0.0618 \\
\hline 4 & Yangon & 0.6395 & 29 & $\begin{array}{l}\text { Kuala } \\
\text { Lumpur }\end{array}$ & 0.2384 & 54 & Ankara & 0.1154 & 79 & Abidjan & 0.0575 \\
\hline 5 & Chittagong & 0.6326 & 30 & $\begin{array}{l}\text { Rio de } \\
\text { Janeiro }\end{array}$ & 0.2283 & 55 & Changchun & 0.1073 & 80 & Dhaka & 0.0522 \\
\hline 6 & Toronto & 0.5481 & 31 & Melbourne & 0.2126 & 56 & Suzhou & 0.1071 & 81 & Wuhan & 0.0515 \\
\hline 7 & Ahmadabad & 0.5439 & 32 & $\begin{array}{l}\text { Belo } \\
\text { Horizonte }\end{array}$ & 0.2106 & 57 & Dalian & 0.1047 & 82 & Kolkata & 0.0455 \\
\hline 8 & Dallas & 0.5223 & 33 & Barcelona & 0.2043 & 58 & Bogota & 0.1041 & 83 & $\begin{array}{c}\text { Buenos } \\
\text { Aires }\end{array}$ & 0.0426 \\
\hline 9 & Kinshasa & 0.5063 & 34 & Singapore & 0.2023 & 59 & Shanghai & 0.1035 & 84 & Jinan & 0.0423 \\
\hline 10 & Surat & 0.4721 & 35 & Chongqing & 0.1917 & 60 & Sydney & 0.0984 & 85 & Jakarta & 0.0371 \\
\hline 11 & Moscow & 0.4671 & 36 & Bangalore & 0.1882 & 61 & Guangzhou & 0.0973 & 86 & Riyadh & 0.0323 \\
\hline 12 & Fortaleza & 0.4664 & 37 & Chennai & 0.1836 & 62 & Nanjing & 0.0937 & 87 & Tokyo & 0.0283 \\
\hline 13 & Pune & 0.4339 & 38 & Shenzhen & 0.1830 & 63 & New York & 0.0905 & 88 & Fukuoka & 0.0231 \\
\hline 14 & Boston & 0.4206 & 39 & Delhi & 0.1818 & 64 & Nagoya & 0.0899 & 89 & $\begin{array}{l}\text { St } \\
\quad \text { Petersburg }\end{array}$ & 0.0211 \\
\hline 15 & Houston & 0.4183 & 40 & Madrid & 0.1802 & 65 & Tianjin & 0.0897 & 90 & Osaka & 0.0169 \\
\hline 16 & Alexandria & 0.4158 & 41 & Hangzhou & 0.1793 & 66 & Sao Paulo & 0.0848 & 91 & Khartoum & 0.0160 \\
\hline 17 & Seoul & 0.4023 & 42 & Foshan & 0.1792 & 67 & $\begin{array}{l}\text { Ho Chi Minh } \\
\text { City }\end{array}$ & 0.0818 & 92 & Lima & 0.0154 \\
\hline 18 & Johannesburg & 0.3929 & 43 & Chicago & 0.1774 & 68 & Karachi & 0.0807 & 93 & Jeddah & 0.0139 \\
\hline 19 & Paris & 0.3918 & 44 & Hong Kong & 0.1710 & 69 & Tehran & 0.0776 & 94 & $\begin{array}{c}\text { Mexico } \\
\text { City }\end{array}$ & 0.0039 \\
\hline 20 & Montreal & 0.3263 & 45 & Xiamen & 0.1641 & 70 & Shenyang & 0.0762 & 95 & Guadalajara & 0.0025 \\
\hline 21 & Miami & 0.3181 & 46 & Phoenix & 0.1545 & 71 & Dar es Salaam & 0.0732 & 96 & Baghdad & 0.0024 \\
\hline 22 & Nairobi & 0.3063 & 47 & Lahore & 0.1487 & 72 & Kabul & 0.0723 & 97 & London & 0.0000 \\
\hline 23 & Philadelphia & 0.3023 & 48 & Manila & 0.1476 & 73 & Los Angeles & 0.0706 & 98 & Beijing & -0.0006 \\
\hline 24 & Medellin & 0.2765 & 49 & Lagos & 0.1448 & 74 & Luanda & 0.0703 & 99 & Cairo & -0.0007 \\
\hline 25 & Kunming & 0.2756 & 50 & Dongguan & 0.1296 & 75 & Qingdao & 0.0677 & 100 & Mumbai & -0.0032 \\
\hline
\end{tabular}

Speed is measured as $250 \mathrm{~m} / \mathrm{yr}$

our aim was to provide a global ranking based on the values of these estimates relative to each other.

This global ranking relies solely on the distribution and dynamics of EVIs and thus can serve as a nullmodel benchmark score for explaining the variation of invasibility in cities across the globe. Besides the obvious influence of EVI, more than a quarter of variation in the spreading rate was explained by the seven covariates. Only two factors, including the demographic factor (city population size, POP) and the socioeconomic factor (GDP per capita), were significant predictors of invasive spreading. The results allowed us to sketch a hypothetical picture of urban invasion: invasive plants are more likely to spread rapidly in cities with high GDP per capita and small urban population size; high mean annual precipitation, large human footprint and high human development index could further boost invasive spread. This portrays an urban landscape in a developed country (high GDP per capita) with young 
Table 2 The global ranking of invasion risks measured as the average spreading rate for 40 countries

\begin{tabular}{|c|c|c|c|c|c|c|c|}
\hline Rank & Country & Avg. velocity & \# Cities & Rank & Country & Avg. velocity & \# Cities \\
\hline 1 & Myanmar & 0.64 & 1 & 21 & Philippines & 0.15 & 1 \\
\hline 2 & Congo & 0.51 & 1 & 22 & Nigeria & 0.14 & 1 \\
\hline 3 & Canada & 0.44 & 2 & 23 & China & 0.12 & 24 \\
\hline 4 & South Korea & 0.40 & 1 & 24 & Pakistan & 0.11 & 2 \\
\hline 5 & South Africa & 0.39 & 1 & 25 & Viet Nam & 0.08 & 1 \\
\hline 6 & France & 0.39 & 1 & 26 & Iran & 0.08 & 1 \\
\hline 7 & USA & 0.38 & 11 & 27 & Tanzania & 0.07 & 1 \\
\hline 8 & Bangladesh & 0.34 & 2 & 28 & Afghanistan & 0.07 & 1 \\
\hline 9 & Brazil & 0.33 & 5 & 29 & Angola & 0.07 & 1 \\
\hline 10 & Kenya & 0.31 & 1 & 30 & Chile & 0.06 & 1 \\
\hline 11 & India & 0.26 & 9 & 31 & Ivory Coast & 0.06 & 1 \\
\hline 12 & Thailand & 0.25 & 1 & 32 & Mexico & 0.04 & 3 \\
\hline 13 & Russia & 0.24 & 2 & 33 & Argentina & 0.04 & 1 \\
\hline 14 & Malaysia & 0.24 & 1 & 34 & Japan & 0.04 & 4 \\
\hline 15 & Egypt & 0.21 & 2 & 35 & Indonesia & 0.04 & 1 \\
\hline 16 & Singapore & 0.20 & 1 & 36 & Saudi Arabia & 0.02 & 2 \\
\hline 17 & Spain & 0.19 & 2 & 37 & Sudan & 0.02 & 1 \\
\hline 18 & Colombia & 0.19 & 2 & 38 & Peru & 0.02 & 1 \\
\hline 19 & Turkey & 0.18 & 2 & 39 & Iraq & $<0.01$ & 1 \\
\hline 20 & Australia & 0.16 & 2 & 40 & United Kingdom & 0.00 & 1 \\
\hline
\end{tabular}

Speed is measured as $250 \mathrm{~m} /$ year

Table 3 Velocity explained by the seven explanatory variables

\begin{tabular}{lllrrrrr}
\hline Variable & Estimate & S.E. & $\mathrm{t}$ & $\mathrm{P}$ & $\mathrm{I}$ & $\mathrm{J}$ & Total \\
\hline MAP & $4.10 \mathrm{E}-05$ & $3.87 \mathrm{E}-05$ & 1.057 & 0.293 & 0.026 & 0.009 \\
MAT & $-1.82 \mathrm{E}-03$ & $3.67 \mathrm{E}-03$ & -0.496 & 0.622 & 0.002 & -0.002 & $<0.036$ \\
HDI & $8.93 \mathrm{E}-04$ & $9.35 \mathrm{E}-04$ & 0.955 & 0.343 & 0.014 & $<0.001$ & 0.014 \\
HF & $3.96 \mathrm{E}-03$ & $2.31 \mathrm{E}-03$ & 1.717 & 0.090 & 0.017 & -0.011 & 0.006 \\
POP & $-1.10 \mathrm{E}-05$ & $3.41 \mathrm{E}-06$ & -3.238 & 0.002 & 0.096 & -0.011 & 0.085 \\
PGR & $6.65 \mathrm{E}-03$ & $1.66 \mathrm{E}-02$ & 0.400 & 0.690 & 0.002 & -0.001 & 0.001 \\
GDPpc & $4.52 \mathrm{E}-06$ & $1.93 \mathrm{E}-06$ & 2.347 & 0.022 & 0.108 & 0.036 & 0.144 \\
\hline
\end{tabular}

Speed is measured as $250 \mathrm{~m} /$ year

S.E. standard error, $t$ and $P t$ test statistics, $I, J$ and Total independent, joint and total contribution of each explanatory variable to variance explained

history/demography (thus small urban population size). Such urban landscapes are often associated with large low-density residential areas with gardens and parks, and elevated surface-soil disturbance from road-verge maintenance and housing development. Our results therefore add support to pinpointing suburban gardens in low-density residential areas as hubs and sources for urban invasions involving mostly horticultural plants (Pyšek et al. 1998; Alston and Richardson 2006; Gravier-Pizarro et al. 2010; Dyderski et al. 2015). 
Fig. 3 Hierarchical partitioning of the independent contribution of each explanatory variable to the variation of spreading velocity. MAP mean annual precipitation, $M A T$ mean annual temperature, $P O P$ city population size at 2010 , $P G R$ city population growth rate from 2010 to $2015, H F$ human footprint index, GDPpc gross domestic product per capita at purchasing power parity, HDI country-level human development index

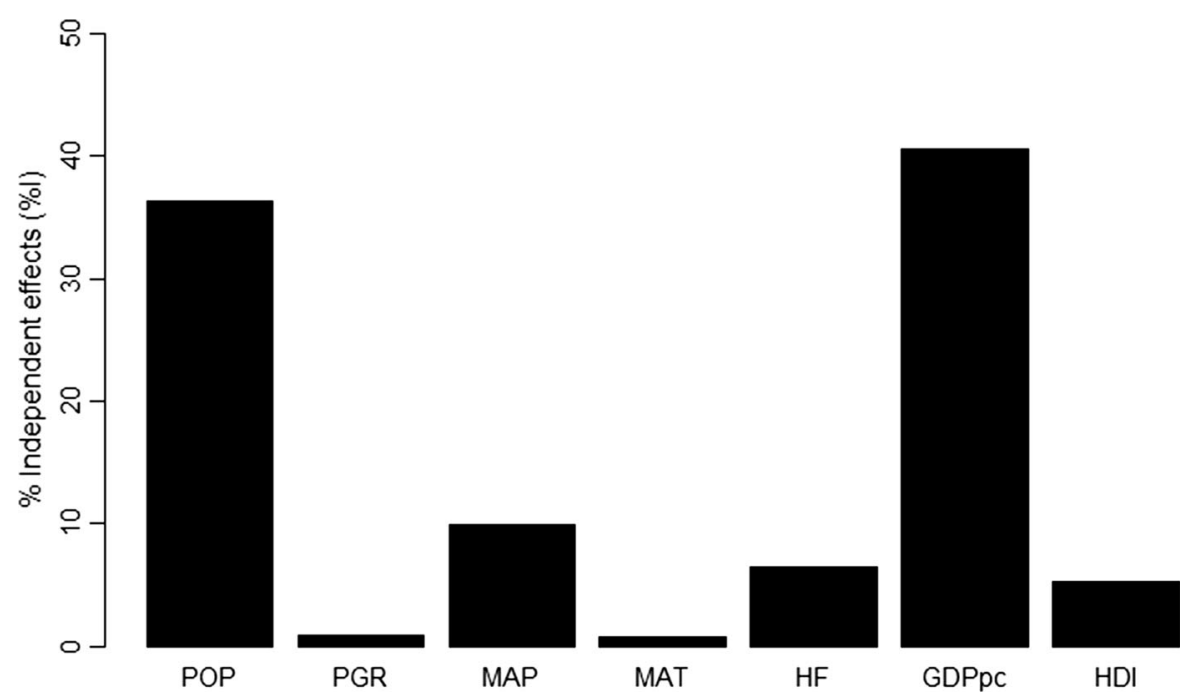

Management actions needed to deal with problematic invasive species are diverse, with attention primarily required to address pre-border prevention by establishing rules and norms, at-border screening, post-border early detection, and rapid response. However, for established species, a different set of management options is needed (Hulme 2003). Our simulated urban invasions highlighted a few key factors for successful invasive spread through UGAs(i) permanent propagule sources, likely to be backyards in upper-income residential areas, that are often inaccessible to invasion monitoring and management; (ii) high-quality UGAs (with high EVI scores) if managed inefficiently, creating secondary sources for rapid invasions, while low-quality UGAs might still support sink populations, creating difficulties for eradication; (iii) multiple loosely connected UGAs that are under uncoordinated invasion management, with the persistence of invasive populations maintained via the rescue effect of metapopulations. Successful invasion management, thus, needs to systematically address these factors. First, the inaccessibility of private property by management teams can seriously hamper any management attempts, particularly in well-governed cities where UGAs are otherwise likely well managed. Vimercati et al. (2017) showed that the attempt to control the guttural toad (Sclerophrys gutturalis) in suburban Cape Town failed because a few private properties were not accessible to managers. These inaccessible sites could be responsible for both the initial introduction and secondary sources of invasion expansion. Accurate monitoring of invasive populations in private properties also creates potential conflicts with rights of private property. A single permanent source in our simulations can ensure successful invasion in the cities even if all other populations suffer from local extinction (due to invasion management). As long as public awareness campaigns cannot successfully guide the action of the entire public, such campaigns, which are often costly, will have little effect on eradication efforts, and could only slow down or contain the invasion. As such, resolving conflicts between invasion management and basic human rights of private property and privacy is the most urgent and important issue to be addressed.

Second, invasive populations in high- and lowquality UGAs often serve different roles during the invasion expansion. High-quality UGAs can support source/core populations, whereas low-quality UGAs can serve as stepping stones and vanguards for invasion. For species with limited dispersal capacity, control efforts should target vanguard populations to hamper rapid range expansion (Wadsworth et al. 2000). This simple rule of thumb has been especially well supported for slowing the spread of invasive trees (e.g. Watson 1985; Moody and Mack 1988; Doren and Jones 1997; Higgins et al. 2000). For species with the capacity for long-distance dispersal, particularly plant species with seeds dispersed by vectors, priority should be given to first controlling large source populations so that the primary propagule supply to long-distance dispersal is reduced, thus blocking the 
further emergence of vanguard, satellite populations (Hulme 2003). This is crucial since core populations typically have the longest residence times and potentially the greatest densities and impacts per capita (Maxwell et al. 2009). For instance, the control of common rhododendron, Rhododendron ponticum, in the UK has targeted mature reproductive plants first because of the large numbers of seeds they produce (Edwards 2006; Harris et al. 2009). In practical terms, however, the rule of thumb discussed above requires that the location of source and peripheral populations is known and accessible; if this is not the case then UGAs with high EVIs or suitability to the invasive species should be prioritised (Caplat et al. 2014).

Finally, the level of UGA isolation and connectivity plays an important role in facilitating invasion expansion and is also an important consideration when prioritizing management. Loosely connected local populations, even if they all suffer from local extinction from temporal local-scale eradication, can still persist at the landscape or regional scale through the rescue effect (Levins 1969; Hanski 1999), especially under fluctuating environments that can further inflate regional population growth (Gonzalez and Holt 2002; Cuddington and Hastings 2016). This requires coordinated synchronised invasion management to break the rescue effect. Invasions initiated from the centre of the landscape or well-connected patches generate higher potential damage as the invasion can spread through the landscape more rapidly, while control costs may be lower for invasions that begin close to landscape boundaries (Epanchin-Niell and Wilen 2012). Moreover, invasion management could also take advantage of areas with low or no UGAs as dispersal barriers so that invasive populations can be cost-efficiently contained in isolated areas.

Urbanisation is only one of the potential drivers of vegetation change. Other key factors in urban environments include climate change, eutrophication/pollution and altered fire frequency. Temperatures in urban environments are higher than those in surrounding rural areas due to the heat island effect, potentially representing the future of local climate. Temporal turnover of species in urban environments could potentially be driven more significantly by rising temperatures than by urbanization (Nobis et al. 2009). Invasibility of many UGAs such as horticultural meadows in city parks is strongly related to resource availability (Cascorbi 2007). Urban vegetation is more nitrophilous than rural woodlands (Vallet et al. 2010), probably due to enhanced nitrogen deposition from air pollution in cities (Weiss 1999). Fires tend to be more common in natural and semi-natural areas at the urban fringe (Price and Bradstock 2014). Fire is also often used for short-term removal of non-native plants, but this can also stimulate seed germination of non-native species in nutrient-enriched areas after fire (Thomson and Leishman 2005). All the above factors and other interact in complex ways to presence and abundance of specific non-native species (Marozas et al. 2015) and need to be incorporated in simulations for particular urban environments. However, for the global comparison in this paper, our simple model that only considered each city's EVIs provided a platform for increased realism for invasions in specific cities.

Acknowledgements A preliminary version of this paper was presented at the November 2016 workshop on "Non-native species in urban environments: patterns, processes, impacts and challenges" hosted and funded by the DST-NRF Centre of Excellence for Invasion Biology in Stellenbosch, South Africa. We are grateful for the many comments and suggestions from workshop participants. $\mathrm{CH}$ is supported by the South African Research Chair Initiative (SARChI), the National Research Foundation of South Africa (Grant Numbers 81825 and 76912), and the Australian Research Council (Discovery Project DP150103017). DMR acknowledges support from National Research Foundation of South Africa (Grant 85417).VV is supported by a research grant from the African Climate Development Initiative (ACDI).

\section{References}

Ahlenius H (2010) World large urban areas, 1950-2050. Nordpil. http://nordpil.com//resources/world-database-oflarge-cities/

Aikio S, Duncan RP, Hulme PE (2010) Herbarium records identify the role of long-distance spread in the spatial distribution of alien plants in New Zealand. J Biogeogr 37:1740-1751

Alston KP, Richardson DM (2006) The roles of habitat features, disturbance, and distance from putative source populations in structuring alien plant invasions at the urban/wildland interface in the Cape Peninsula, South Africa. Biol Cons 132:183-198

Basnou C, Iguzquiza J, Pino J (2015) Examining the role of landscape structure and dynamics in alien plant invasion from urban Mediterranean coastal habitats. Landscape Urban Plan 136:156-164

Berube A, Trujillo JL, Ran T, Parilla J (2015) Global metro monitor. The Brookings Institution. https://www. brookings.edu/research/global-metro-monitor/. Accessed 11 October 2016 
Brockmann D, Hufnagel L, Geisel T (2006) The scaling laws of human travel. Nature 439:462-465

Caplat P, Hui C, Maxwell BD, Peltzer DA (2014) Cross-scale management strategies for optimal control of trees invading from source plantations. Biol Invasions 16:677-690

Carroll SP, Dingle H (1996) The biology of post-invasion events. Biol Cons 78:207-214

Cascorbi U (2007) Integration of invasion ecology theories into the analysis of designed plant communities: a case study in Southern Germany. Landscape Ecol 22:1371-1381

Cilliers SS, Williams NSG, Barnard FJ (2008) Patterns of exotic plant invasions in fragmented urban and rural grasslands across continents. Landscape Ecol 23:1243-1256

Cuddington K, Hastings A (2016) Autocorrelated environmental variation and the establishment of invasive species. Oikos 125:1027-1034

Diamantidis AD, Papadopoulos NT, Nakas CT et al (2009) Life history evolution in a globally invading tephritid: patterns of survival and reproduction in medflies from six world regions. Biol J Linn Soc 97:106-117

Didan K (2015) MOD13Q1 MODIS/Terra vegetation indices 16-Day L3 global $250 \mathrm{~m}$ SIN grid V006. NASA EOSDIS land processes DAAC. https://doi.org/10.5067/MODIS/ MOD13Q1.006. Accessed 1 December 2016

Donaldson JE, Hui C, Richardson DM et al (2014) Invasion trajectory of alien trees: the role of introduction pathway and planting history. Global Ch Biol 20:1527-1537

Doren RF, Jones DT (1997) Plant management in Everglades National Park. In: Simberloff D, Schmitz DC, Brown TC (eds) Strangers in paradise: impact and management of nonindigenous species in Florida. Island Press, Washington DC, pp 275-286

Dyderski MK, Gdula AK, Jagodzinski AM (2015) “The rich get richer" concept in riparian woody species-a case study of the Warta River Valley (Poznan, Poland). Urb For Urb Green 14:107-114

Edwards C (2006) Managing and controlling invasive Rhododendron. Forestry Commission Practice Guide, Edinburgh

Epanchin-Niell RS, Wilen JE (2012) Optimal spatial control of biological invasions. J Environ Econ Manag 63:260-270

Gonzalez A, Holt RD (2002) The inflationary effects of environmental fluctuations in source-sink systems. Proc Natl Acad Sci USA 99:14872-14877

Gravier-Pizarro GI, Radeloff VC, Stewart SI et al (2010) Housing is positively associated with invasive exotic plant species richness in New England, USA. Ecol Appl 20:1913-1925

Hanski IA (1999) Metapopulation ecology. Oxford University Press, London

Harris CM, Park KJ, Atkinson R et al (2009) Invasive species control: incorporating demographic data and seed dispersal into a management model for Rhododendron ponticum. Ecol Informatics 4:226-233

Higgins SI, Richardson DM, Cowling RW (2000) Using a dynamic landscape model for planning the management of alien plant invasions. Ecol Appl 10:1833-1848

Hijmans RJ, Cameron SE, Parra JL et al (2005) Very high resolution interpolated climate surfaces for global land areas. Int J Climat 25:1965-1978
Hill JK, Collingham YC, Thomas CD et al (2001) Impacts of landscape structure on butterfly range expansion. Ecol Lett $4: 313-321$

Hui C, Richardson DM (2017) Invasion dynamics. Oxford University Press, Oxford

Hui C, Krug RM, Richardson DM (2011) Modelling spread in invasion ecology: a synthesis. In: Richardson DM (ed) Fifty years of invasion ecology: the legacy of Charles Elton. Wiley-Blackwell, Oxford, pp 329-343

Hui C, Roura-Pascual N, Brotons L et al (2012) Flexible dispersal strategies in native and non-native ranges: environmental quality and the 'good-stay, bad-disperse' rule. Ecography 35:1024-1032

Hulme PE (2003) Biological invasions: winning the science battles but losing the conservation war? Oryx 37:178-193

Lee TD, Perkins AL, Campbell AS et al (2015) Incipient invasion of urban and forest habitats in New Hampshire, USA, by the nonnative tree, Kalopanax septemlobus. Invas Plant Sci Manag 8:111-121

Levins R (1969) The effect of random variation of different types on population growth. Proc Natl Acad Sci USA 62:1061-1065

Lyons DA, Scheibling RE (2009) Range expansion by invasive marine algae: rates and patterns of spread at a regional scale. Divers Distrib 15:762-775

Marozas V, Cekstere G, Laivins M, Straigyte L (2015) Comparison of neophyte communities of Robinia pseudoacacia L. and Acer negundo L. in the eastern Baltic Sea region cities of Riga and Kaunas. Urb For Urb Green 14:826-834

Maxwell BD, Lehnhoff E, Rew LJ (2009) The rationale for monitoring invasive plant populations as a crucial step for management. Invasive Plant Sci Manag 2:1-9

McKinney ML (2008) Effects of urbanization on species richness: a review of plants and animals. Urb Ecosyst 11:161-176

McLean P, Gallien L, Wilson JRU et al (2017) Small urban centres as launching sites for plant invasions in natural areas. Biol Invasions. doi:10.1007/s10530-017-1600-4

Meek C, Richardson DM, Mucina L (2010) A river runs through it: land use and the composition of vegetation along a riparian corridor in the Cape Floristic Region, South Africa. Biol Conserv 143:156-164

Melbourne BA, Hastings A (2009) Highly variable spread rates in replicated biological invasions: fundamental limits to predictability. Science 325:1536-1539

Moody ME, Mack RN (1988) Controlling the spread of plant invasions: the importance of nascent foci. J Appl Ecol 25:1009-1021

Nakazawa M (2015) fmsb: Functions for medical statistics book with some demographic data. $\mathrm{R}$ package version 0.5.2. http://minato.sip21c.org/msb/

Nobis MP, Jaeger JAG, Zimmermann NE (2009) Neophyte species richness at the landscape scale under urban sprawl and climate warming. Divers Distrib 15:928-939

Pergl J, Pysek P, Perglova I (2012) Low persistence of a monocarpic invasive plant in historical sites biases our perception of its actual distribution. J Biogeogr 39:1293-1302

Price O, Bradstock R (2014) Countervailing effects of urbanization and vegetation extent on fire frequency on the 
Wildland Urban Interface: disentangling fuel and ignition effects. Landsc Urb Plan 130:81-88

Pyšek P, Hulme PE (2005) Spatio-temporal dynamics of plant invasions: linking pattern to process. Eco Science 12:302-315

Pyšek P, Prach K, Mandak B (1998) Invasions of alien plants into habitats of Central European landscape: an historical pattern. In: Edwards K, Kowarik I, Williamson M (eds) Starfinger U. Plant Invasions, Ecological mechanisms and human responses, pp 23-32

Roura-Pascual N, Bas JM, Thuiller W et al (2009) From introduction to equilibrium: reconstructing the invasive pathways of the Argentine ant in a Mediterranean region. Global Change Biol 15:2101-2115

Song JJ, Hong SK, Kim HO et al (2003) The pattern of landscape patches and invasion of naturalized plants in developed areas of urban Seoul. Landsc Urb Plan 70:205-219

Thomas CD, Cameron A, Green RE et al (2004) Extinction risk from climate change. Nature 427:145-148

Thomson VP, Leishman MR (2005) Post-fire vegetation dynamics in nutrient-enriched and non-enriched sclerophyll woodland. Aust Ecol 30:250-260

UNFPA (2007) State of world population: Unleashing the potential of urban growth. United Nations Population Fund, New York

United Nations, Department of Economic and Social Affairs, Population Division (2014). World Urbanization Prospects: The 2014 Revision. https://esa.un.org/unpd/wup/. Accessed 12 October 2016

United Nations Development Programme (2015) Human development reports. Human development data (19802015). http://hdr.undp.org/en/data. Accessed 11 October 2016
Vallet J, Beaujouan V, Pithon J et al (2010) The effects of urban or rural landscape context and distance from the edge on native woodland plant communities. Biodivers Cons 19:3375-3392

Vimercati G, Hui C, Davies SJ et al (2017) Integrating age structured and landscape resistance models to disentangle invasion dynamics of a pond-breeding anuran. Ecol Model 356:104-116

Von der Lippe M, Kowarik I (2007) Long-distance dispersal of plants by vehicles as a driver of plant invasion. Cons Biol 21:986-996

Wadsworth RA, Collingham YC, Willis SG et al (2000) Simulating the spread and management of alien riparian weeds: are they out of control? J Appl Ecol 37:28-38

Walsh C, MacNally R (2013) The hier. part. Hierarchical partitioning. $\mathrm{R}$ package version $1.0-4$

Watson AK (1985) Leafy Spurge. Monograph 3. Weed Science Society of America, Champaign, IL

Weiss SB (1999) Cars, cows, and checkerspot butterflies: nitrogen deposition and management of nutrient-poor grasslands for a threatened species. Cons Biol 13:1476-1486

Wildlife Conservation Society-WCS, and Center for International Earth Science Information Network-CIESINColumbia University (2005) Last of the Wild Project, Version 2, 2005 (LWP-2): Global Human Footprint Dataset (Geographic). Palisades, NY: NASA Socioeconomic Data and Applications Center (SEDAC). http://dx.doi.org/ 10.7927/H4M61H5F. Accessed 3 March 2017

Yoshida T, Ellner SP, Jones LE et al (2007) Cryptic population dynamics: rapid evolution masks trophic interactions. PLoS Biol 5:e235 